\title{
Designing Rapid Rating System of Smart Economy to Sustain and Develop Cities in Egypt
}

\author{
Eng. Esraa Magdy ${ }^{1}$, Professor Dr. Tarek Zaki ${ }^{2}$, Dr. Walid Bayoumi ${ }^{3}$ \\ ${ }^{1}$ Ph.D Researcher, ${ }^{2}$ Professor Dr, ${ }^{3}$ Associate professor \\ 1, 2, 3 Faculty of Urban \& Regional Planning, Cairo University, Egypt.
}

${ }^{1}$ ORCID: 0000-0002-8688-0218

\begin{abstract}
Interacting with the trends of the concept of sustainable development and trying to achieve it in cities, this thought faced many challenges, especially in the relationship between economic growth and preservation of resources, and since then many trends emerged towards achieving balance between economic growth and achieving sustainability in cities such as (Sustainable City, Eco City, Green City, etc...) and the emergence of environmental economics related to them, leading the trend towards Sustainable Smart City (SSC).

The concept of Sustainable Smart Cities (SSC) helps us to achieve the balance between the environment and economic growth. That concept based on the resource of information and communication technologies of smart economy. In addition, it seeks to develop all sectors of the city towards smartness.

The sector of economy is one of the most important sectors in the city, because it affects the development and construction of city, so it's better to apply smart economy.

The aim of the research is to adopt the global directives supporting the smartness in cities. So the research designs a rapid initial monitoring of the factors of cities which tries to build smart economies. It helps countries like the Case Study "Egypt" to identify development hotspots in order to facilitate proper development decisions. Because one of the biggest gaps experienced in Egypt where there are no indicators and measurements to measure smartness potential of economy sector. So, the concept of designing a rapid rating system facilitates Egypt to build smart economy.
\end{abstract}

Keywords: (Smart Economy - Technological Economics Rating System - Smart Sustainable City SSC KPI index - smart city)

Abbreviations: ICT (Information Communication Technology) - SSC (Sustainable Smart City) - KPI (Key Performance Indictor) - GDP (Gross Domestic Product) - IT( Information Technology)

\section{INTRODUCTION:}

Since twenty-first century the investments directed to Information and Communications Technology (ICT) when the rate of knowledge creation has increased and associated with economic activities growth. [1] Thus advanced types of techeconomic appeared such as "Knowledge Economy, Competitive Economy, Share Economy, Digital Economy", these types are the most applied in the world, and finally the Smart Economy. [2]

This led to apply smart economy in order to develop classic economic system and integrated Information Technology with activities in the city. [3] Since then the information and communication technology resource was depend on it as a sustainable renewable resource [4], and thus a large part of the economic growth shifted towards sustainability. [5]

In this context many economic activities and services will appear [6], thus some changes will occur in social and urban planning in cities. [7] [8]

However, there are many challenges while applying the smart economy in countries, especially developing countries. Some of these challenges; the lack of studies, indicators and analytical maps on the opportunities for applying it. [2]

The research discusses designing an initial rapid rating system of smart economy to monitor the elements of smart technology economics in cities, those are oriented towards smartness in order to take the best decision to develop these cities and growth smart economy.

\section{LITERATURE REVIEW}

\section{Economic growth and Technology}

The emergence of many technological economic systems has provided a powerful motivate in treatment economic problems in cities, [1] and according to the World Economic Forum for the year 2015, [9] these systems contribute to raising the Gross Domestic Product (GDP) because they increase production efficiency and reduce cost. [10]

As a result of the literature review and previous studies technological economic systems are not implemented in cities according to the time line that mentioned for their appearance [3], but to the vision of the city, needs and moves to smartness. [11] As shown in figure 1 and also it was found that there is dynamic and overlap between technological economic types. It 
is possible to appear more than one type of technological economics in one city. [3] Here is a presentation of a set of concepts of these types agreed in many previous literature and studies. This is a presentation of the most used indicators and express how to find the elements of their construction. As shown in table 1 .

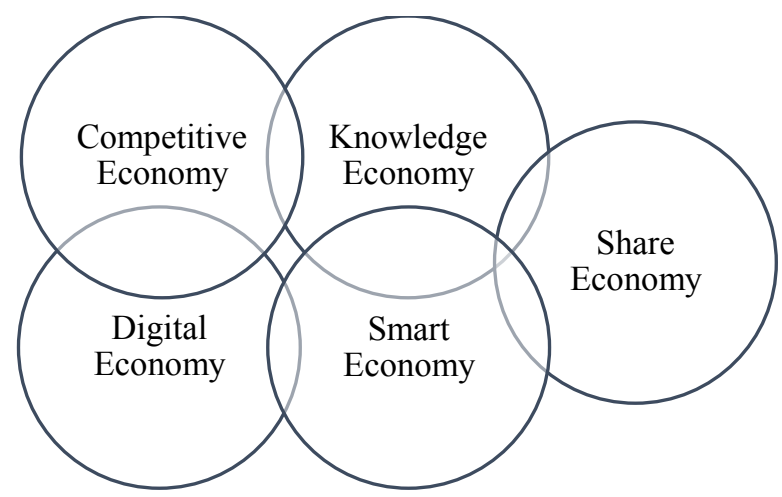

Figure 1: types of technological economic

Table 1 : Definition and indicators for types of technological economics

\begin{tabular}{|c|c|c|}
\hline Types & Definition & Indicators \\
\hline 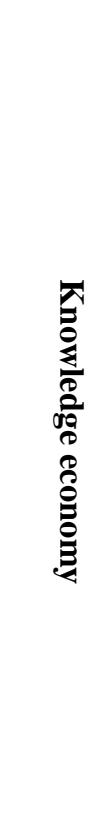 & $\begin{array}{l}\text { It is an economy based on knowledge of the concept } \\
\text { of increasing the use of technology with the current } \\
\text { economy, increasing productivity and providing a } \\
\text { group of skilled workers with more knowledge to } \\
\text { Improve the current economy, but it is not possible } \\
\text { to build a knowledge economy without building } \\
\text { economic stability. [12] }\end{array}$ & $\begin{array}{l}\text { - The rate of developing information and communication } \\
\text { technology bases } \\
\text { - The percentage of the IT sector's contribution to } \\
\text { developing the local product structure and increasing the } \\
\text { products } \\
\text { - Increasing the worker's share of the local product } \\
\text { - The percentage of economic institutions } \\
\text { (entrepreneurship) that implement productive innovations } \\
\text { and modern production technology } \\
\text { - The rates of introducing new technologies into production } \\
\text { methods, especially those that limit waste and reduce } \\
\text { resource use. } \\
\text { - Increased\% of innovative products from the total } \\
\text { industrial production. } \\
\text { - Increase\% of sales of technologically and innovative } \\
\text { industrial products out of total industrial sales. } \\
\text { - Ratio of IT-based products to traditional products } \\
\text { - -Rates of increasing the proportion of trained and } \\
\text { developed workers [13] }\end{array}$ \\
\hline 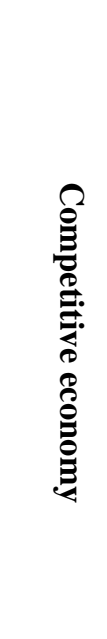 & $\begin{array}{l}\text { Providing the appropriate legal and political } \\
\text { environment to increase the competitive economy, } \\
\text { promote and increase the demand for household } \\
\text { goods, promote and focus on high-quality products } \\
\text { and rely on less costly raw materials, build a broad } \\
\text { base of information that relies on a legal } \\
\text { administrative system and promote higher } \\
\text { innovative projects to increase competitiveness and } \\
\text { increase cooperation between small enterprises to } \\
\text { form A conglomerate that increases competitiveness } \\
{[14]}\end{array}$ & $\begin{array}{l}\text { - The rationalization of the use of non-renewable energy } \\
\text { - The volume of foreign investment wave } \\
\text { - Profit rates } \\
\text { - The extent of raising the comparative advantage of the } \\
\text { empty economy } \\
\text { - Increase productivity } \\
\text { - Costs of trained labor } \\
\text { - The size of growth in exports from small and medium } \\
\text { enterprises } \\
\text { - The rates of the contribution of the mutual production in } \\
\text { the volume of antibiotics from the local product } \\
\text { - Technology Contribution to Trade } \\
\text { - Small enterprise growth rates } \\
\text { - The volume of costs of using local resources [15] }\end{array}$ \\
\hline
\end{tabular}




\begin{tabular}{|c|c|c|}
\hline Types & Definition & Indicators \\
\hline 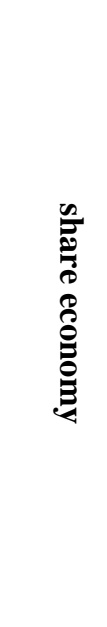 & $\begin{array}{l}\text { It is a system based on the principle of sharing human } \\
\text { and material assets to limit the accelerated depletion } \\
\text { of resources as it began its approach as a way to reach } \\
\text { sustainable development. } \\
\text { It improves the local development of the local } \\
\text { economy through the idea of sharing resources and } \\
\text { assets, and this can happen between capital, labor, } \\
\text { etc. It is possible with participation in the work of the } \\
\text { web site for the promotion [16] }\end{array}$ & $\begin{array}{l}\text { - The percentage of increasing the financing of } \\
\text { technological infrastructure projects from government } \\
\text { funding } \\
\text { - E-commerce volume } \\
\text { - Percentage of the volume of internal investments } \\
\text { resulting from the existence of an ICT } \\
\text { - Number of households used to shop online } \\
\text { - The number of workers in independent businesses via the } \\
\text { internet } \\
\text { - The number of users on smartphones } \\
\text { - Number of companies with a web sit } \\
\text { - Number of social media users } \\
\text { - Number of companies with special speeds on the Internet } \\
\text { [17] }\end{array}$ \\
\hline 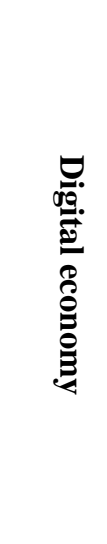 & $\begin{array}{l}\text { There is no clear definition of the digital economy, } \\
\text { but the concept and idea of creating the digital } \\
\text { economy of a country or city is based on the quality } \\
\text { of the digital infrastructure consisting of the quality } \\
\text { of information and communication technology, the } \\
\text { nature of the consumer and the extent of its dealings } \\
\text { with digital and technological services and electronic } \\
\text { platforms and therefore the volume of electronic } \\
\text { commerce and the provision of services via the } \\
\text { Internet [18] }\end{array}$ & $\begin{array}{l}\text { - The total volume of services related to electronic } \\
\text { platforms } \\
\text { - The free availability of digital services to families and } \\
\text { industrial establishments } \\
\text { - Number of companies using and connected to the internet } \\
\text { - Number of individuals using digital services } \\
\text { - The number of families connected to the Internet } \\
\text { - The number of families using online purchases } \\
\text { - The number of companies used for Internet marketing } \\
\text { - Number of commercial sales online } \\
\text { - Number of private companies that rely on information } \\
\text { and communications technology [19], [20] }\end{array}$ \\
\hline
\end{tabular}

There are many definitions for smart economy analyzing which concluded that the concept of smart economy can be formulated as the last type of technological economics which helps the cities to change the frame work of current economy. [4] It combines features of technological economics "knowledge economy, Competitive economy, share economy, digital economy" with the current economy to increase productivity and raise environmental efficiency [6], [2].

The previous researches and studies confirmed that the definition of smart economy, resulted of improvement and overlap the creation the technological economics system in cities.

It adds its properties to the most important sectors in the city "E-Commerce - E-Banking - E-Finance - E-Business Business Administration and Entrepreneurship - E-Tourism Sector "and it encourages policies "Entrepreneurship innovation - marketing - local competitiveness - ability to transform - labor market flexibility - Productivity" [6], [2]

There are many approaches to apply the smart economy in city. This is one of these approaches is a level of achievement [5] that expresses the needs of building smart economy in cities. As the main idea of smart economy confirmed that it is based on developing systems to build it. To apply the level of achievement we have to pass the three stages of building smart economy.
The first stage" Basic" which expresses the necessity of providing a technological environment and building the ICT infrastructure for growth up the local economy and transforming to smart economy center. [5]

The second stage " Medium Importance Needs" to build smart economy, which focuses on what are the effects of smart economic growth, what are the elements that express this growth. [5]

The third stage "advanced" the growth of smart economic activities and their contribution to deal with environmental, economic and social problems. This stages as shown in table 2 [5]

Table 2: Level of achievements approach

\begin{tabular}{|l|l|l|}
\hline \multirow{5}{*}{$\begin{array}{l}\text { Smart } \\
\text { economy }\end{array}$} & $\begin{array}{l}\text { Level of } \\
\text { achievement }\end{array}$ & Description \\
\cline { 2 - 3 } & Basic & $\begin{array}{l}\text { - Facilitating local economic } \\
\text { activities } \\
\text { - Infra-structure facilities } \\
\text { economic support system } \\
\text { - Integrated ICT based } \\
\text { economic hub }\end{array}$ \\
\cline { 2 - 3 } & $\begin{array}{l}\text { Eedium - } \\
\text { important }\end{array}$ & $\begin{array}{l}\text { Economic growth and value } \\
\text { creation }\end{array}$ \\
\cline { 2 - 3 } & Advanced & Innovative economic growth \\
\hline
\end{tabular}




\section{METHODOLOGY}

The methodology of designing a rapid initial rating system of smart economy that expresses how to identify the elements of cities, especially those are oriented towards smartness in developing countries, such as the case study (Egypt) to facilitate access a proper way to make a development decision.

The methodology includes a set of steps as follows first step" the identification the vision of country and city". [8] The second step" designing a rapid rating system of smart economy" the appropriate for the Egyptian case. That Egypt suffers from a poverty in databases which we can use to build the classification and identification of opportunities and capabilities, so we select measurable indicators according to the case study.

So it was relied on smart sustainable city SSC KPI index [9], smart city index ICT infra-structure [21] and Create a set of indicators stemming from the technological economics types. The third step is to create rating system consisting of indicators which express the concept of smart economic. The fourth step is using Level of achievement approach to facilitate making decision. The final step is making perfect decision to grow smart economic up and localization projects and services for smart economy. [8]

In order to determine which stage the city reaches to apply smart economy according to the approach of a level of achievement to make appropriate decisions and settlement projects which expected in these cities. as shown in Figure2

City indicator must help the city's stakeholders "to better understand their challenges, and provide them with insights on effective policies and best practices and support their decision making. [22]

As for the new cities, the stakeholders should take into consideration the vision of smartness and sustainable of the city. Then the basics and criteria of sectors will be established according to the framework of smart city within smart economy. [22] [23]

\begin{tabular}{|c|c|}
\hline first step & $\begin{array}{l}\text { - focus on plan for shift to smartness } \\
\text { - vision of city } \\
\text { - vision of country }\end{array}$ \\
\hline $\begin{array}{l}\text { second } \\
\text { step }\end{array}$ & $\begin{array}{l}\text { - design smart economy rating system } \\
\text { - sustainble smart city performance kpi index } \\
\text { - ict infra structure } \\
\text { - smart city index focuse on smart economy indecators } \\
\text { - creation a set of indicators stemming from the economic technological types }\end{array}$ \\
\hline third step & $\begin{array}{l}\text { - smart economy rating system } \\
\text { - smart economy index for rating to monitor opportunity in cities to shift }\end{array}$ \\
\hline fourth step & $\begin{array}{l}\text { - smart economy rating system approches } \\
\text { - Level of achievement ( basic - medium - advanced ) to facilitate make decision }\end{array}$ \\
\hline Final step & $\begin{array}{l}\text { - making the best decision to grow up smart economic and localization projects and services for } \\
\text { smart economy. }\end{array}$ \\
\hline
\end{tabular}

Figure 3:Methodology of designing rapid rating system of smart economy

\section{Case study}

One of the directives of Egypt 2030 strategy is following SDGS goals especially goals about apply smart cities concept in new cities, whether the existing cities or in the under construction stage cities (as shown in fig 4).
Then the interest in developing economics to smart So adoption the economic goals such as "the criterion of entrepreneurship, productivity, the development of information technology" and also created a set of eight goals for economic development, Especially the integration of the informal sector marketing via 
the Internet, to become an integrated with the local economy, as well as the extent of its contribution for providing job opportunities in addition to maximize the benefit of the digital economy leading to smart economy. [24]

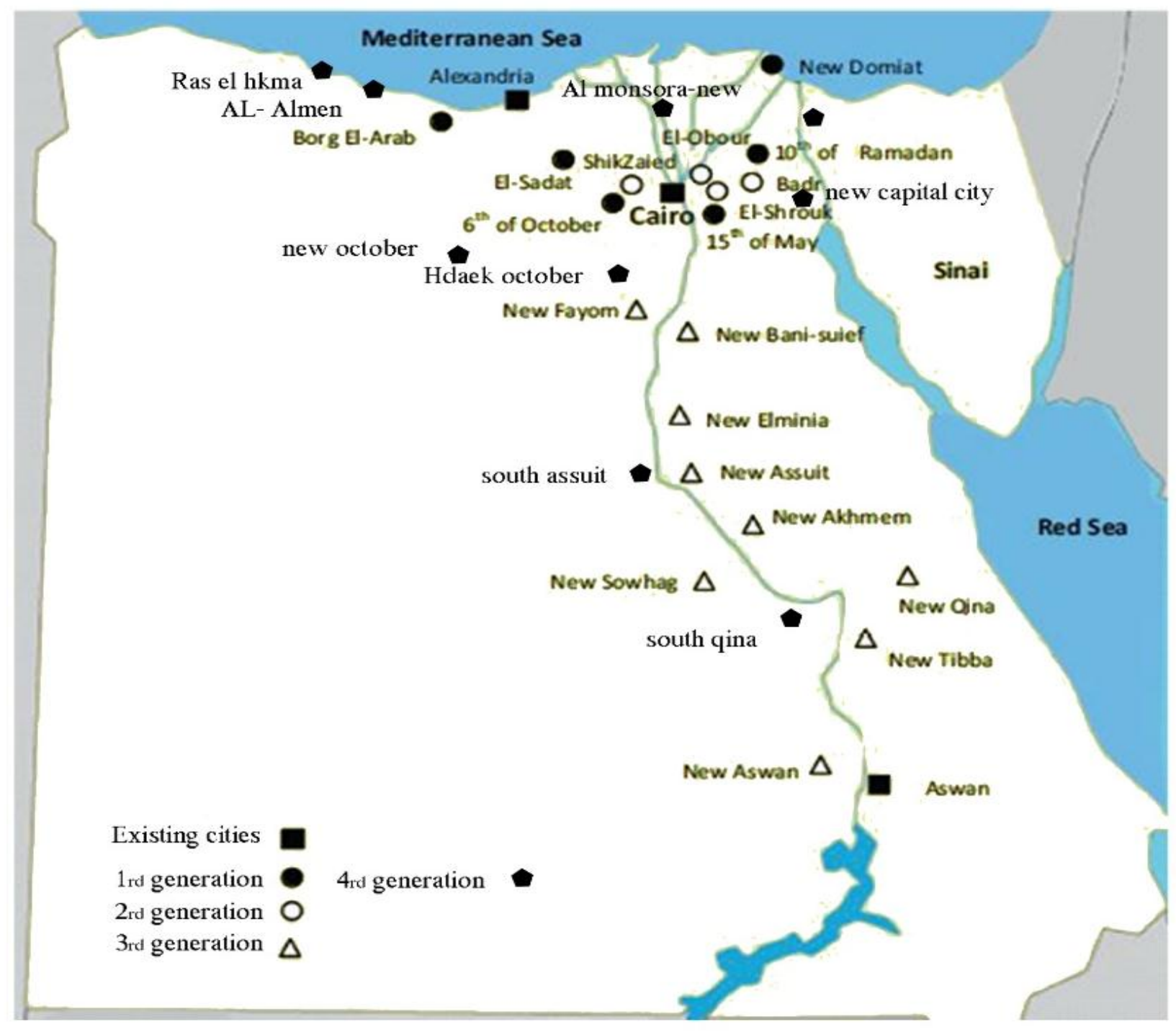

Figure 4: new cities (existing - under construction) in Egypt

Among the most important goals of the state is to integrate information and communications technology with the economic sector, and a number of goals have emerged, including the integration of information technology in various economic sectors to increase the efficiency and productivity of these sectors. [24]

Moreover open new markets to the information technology industry and try to provide communication services at low prices There was a national goal that Egypt try to establish a global digital center by developing cities and pumping a group of projects for a group of cities,

Although the dilemma in Egypt There is no classification of cities according to indicators of building smart economy to facilitate the selection of cities in which to transform the current economic systems into smart. [24]

Therefore the importance of designing a rapid initial rating system for Egypt to identify these components, factors and focus to move towards the transformation of the current economies in cities to smart economy.

\section{RESULT and DISCUSSION}

\section{Design rating system}

It is a tool for building and selecting projects based on studies of needs, especially in cities those are geared towards smartness. This system aims to design an initial rapid rating system to identify the main ingredients which support the presence of technological projects. 
While starting to design the rating system, we should search for detailed indicators which express the needs of building a smart economy, thus we found weaknesses in the smart city index, [25] especially the economic sector, those indicators do not reflect the main concept and the basic elements of building a smart economy, because detailed indicators must be obtained clearly to express it.

Through the literature and previous studies about the concept of smart economy, it is necessary to search for indicators which reflect the extent of the cities' transformation towards smartness, [23] indicators related to the availability of technological infrastructure, and also indicators which reflect the extent of development in building technological economies in the city we try to link these indicators to reach a set of detailed indicators to monitor initially possibilities of developing the current economy into a smart economy.

According to the case study and the challenges it faces in data availability, [24] a level of achievement is appropriate for this case as being able to monitor the basic and initial ingredients, especially cities which are in the process of being launched towards smartness to develop [23] in this direction and localize many technological projects. [8]

\section{Rating system of smart economy}

The rapid rating system consists of the following: The first group contains indicators which identify in principle the extent of the trend towards smartness in cities in addition to the availability of the infrastructure for information and communication technology.

The second group contains the formation of a set of indicators stemming from the indicators of the component economic stages and qualifying for the smart economy in addition to the indicators which related to the smart economy within smart city index. [21]

All indicators for the rapid rating system for smart economy will be collected from firstly sustainable smart performance KPI index, as mentioned earlier, the purpose of it is to identify what is the availability of opportunities to shift towards smartness in cities. Secondly, the ICT Infrastructure indictors [21], also the goal is to identify the availability of technological infrastructure in the city. Thirdly smart economy indicators from smart city index. [6]

Finally the set of indicators are consisting of the development of economic systems which contribute to building the smart economy, because the city cannot reach the smart economies except with the occurrence of linking and interconnection between these systems to develop the current economic system.

\section{Analysis data collection}

The research has introduced and analyzed all dimensions and factors for the formulation of rating system for smart economy.
Firstly sustainable smart performance KPI index [9] we select this because it reflects the criteria of building a smart city in general so we do not need detailed indicators to express that. It is one of methodology steps for designing rating system to identify the characteristics of the city [25]. as shown in table 3

Table 3: dimension of SSC-KPI [9]

\begin{tabular}{|l|l|}
\hline Dimension & Sub-dimension \\
\hline $\begin{array}{l}\text { Information } \\
\text { communication } \\
\text { technology }\end{array}$ & $\begin{array}{l}\text { Network and access, services and } \\
\text { information plate form ,information } \\
\text { security and privacy }\end{array}$ \\
\hline $\begin{array}{l}\text { Environmental } \\
\text { sustainability }\end{array}$ & $\begin{array}{l}\text { Air quality - energy - indoor pollution } \\
\text { waters }\end{array}$ \\
\hline Productivity & $\begin{array}{l}\text { Capital investment - trade , house hold } \\
\text { income - innovation knowledge } \\
\text { economy-savings export,import }\end{array}$ \\
\hline $\begin{array}{l}\text { Quality of life } \\
\text { Equity and }\end{array}$ & $\begin{array}{l}\text { Education ,health,safety, security public } \\
\text { place and comfort }\end{array}$ \\
\hline $\begin{array}{l}\text { Inequity of income consumption (GINI) } \\
\text { infrastructure } \\
\text { services and infra-structure ,openness } \\
\text { and public participation }\end{array}$ \\
\hline $\begin{array}{l}\text { infra-structure connection to services - } \\
\text { water } \\
\text { infra-structure connection to services- } \\
\text { sewage } \\
\text { infra-structure connection to services- } \\
\text { electric } \\
\text { infra-structure connection to services- } \\
\text { waste management } \\
\text { connection to service - knowledge } \\
\text { infrastructure } \\
\text { infra-structure connection to services- } \\
\text { transport } \\
\text { infra-structure connection to services- } \\
\text { building - living spaces - housing }\end{array}$ \\
\hline
\end{tabular}

Secondly, the ICT Infrastructure indictors, [9] these indicators reflect the availability of technological infrastructure we taken from smart city index because we need detailed indicators for this step which they are an important part of building smart economy, we have to classify according to this approach "level of achievement" by-an initial evaluation (relevant aspect - less relevant aspect) to determine the indicators in any category. as shown in table 4 
Table 4: ICT Infrastructure indictors [6]

\begin{tabular}{|c|c|c|c|c|}
\hline Dimension & Indictor & basic & $\begin{array}{l}\text { Medium - } \\
\text { important }\end{array}$ & advanced \\
\hline Household Internet Access & Percentage of households with Internet access & & & \\
\hline $\begin{array}{l}\text { Fixed Broadband } \\
\text { Subscriptions }\end{array}$ & $\begin{array}{l}\text { Percentage of households with fixed (wired) } \\
\text { broadband }\end{array}$ & & & \\
\hline $\begin{array}{l}\text { Wireless Broadband } \\
\text { Subscriptions }\end{array}$ & $\begin{array}{l}\text { Wireless broadband subscriptions per } 100,000 \\
\text { inhabitants }\end{array}$ & & & \\
\hline $\begin{array}{l}\text { Wireless Broadband } \\
\text { Coverage }\end{array}$ & $\begin{array}{l}\text { Percentage of the city served by wireless } \\
\text { broadband (by technology }\end{array}$ & & & \\
\hline $\begin{array}{l}\text { Availability of WIFI in } \\
\text { Public Areas }\end{array}$ & Number of (public) WIFI hotspots in the city & & & \\
\hline
\end{tabular}

relevant aspect

less relevant aspect

Thirdly smart economy indicators from smart city index, [6], [21] these indicators do not express how to build smart economy in cities, but they contain a set of dimensions which measures the reflection of applying the smart economy on the current economy, we have to classify according to this approach "level of achievement" by-an initial evaluation (relevant aspect - less relevant aspect) to determine the indicators in any category. as shown in table 5

Table 5: smart economy indictors from smart city index [6]

\begin{tabular}{|c|c|c|c|c|}
\hline $\begin{array}{l}\text { Smart } \quad \text { economy- } \\
\text { Dimension }\end{array}$ & Indictor & basic & $\begin{array}{l}\text { Medium }- \\
\text { important }\end{array}$ & advanced \\
\hline \multirow{3}{*}{ Innovative spirit } & R\&D expenditure in $\%$ of GDP & & & \\
\hline & $\begin{array}{l}\text { Employment rate in knowledge-intensive } \\
\text { sectors }\end{array}$ & & & \\
\hline & Patent applications per inhabitant & & & \\
\hline \multirow{2}{*}{ Entrepreneurship } & Self-employment rate & & & \\
\hline & New businesses registered & & & \\
\hline $\begin{array}{l}\text { Economic image } \\
\& \text { trademarks }\end{array}$ & Importance as decision-making center (HQ etc.) & & & \\
\hline Productivity & GDP per employed person & & & \\
\hline \multirow{2}{*}{$\begin{array}{lr}\text { Flexibility } & \text { of } \\
\text { Unemployment } & \text { rate } \\
\text { regional } & \\
\text { labor market } & \end{array}$} & Proportion in part-time employment & & & \\
\hline & Unemployment rate & & & \\
\hline $\begin{array}{l}\text { International } \\
\text { embeddedness }\end{array}$ & $\begin{array}{l}\text { Companies with HQ in the city quoted on } \\
\text { national } \\
\text { stock market }\end{array}$ & & & \\
\hline
\end{tabular}

relevant aspect

less relevant aspect 
International Journal of Engineering Research and Technology. ISSN 0974-3154, Volume 13, Number 11 (2020), pp. 3431 -3443

(C) International Research Publication House. https://dx.doi.org/10.37624/IJERT/13.11.2020.3431-3443

Finally creation a set of indicators stemming from the indicators of economic technological types. [26], [15] , [17], [19] All the previously mentioned indicators will be selected according to its link to the construction of technological economic systems and its easily using within the rating system.in order to use these indictors easily we have to classify according to this approach "level of achievement" by-an initial evaluation (relevant aspect - less relevant aspect) to determine the indicators in any category as shown in table 6

Table 6: an initial evaluation (relevant aspect - less relevant aspect) to determine the indicators according to "level of achievement" approach

\begin{tabular}{|c|c|c|c|c|}
\hline $\begin{array}{l}\text { Types of } \\
\text { Tec- } \\
\text { economic }\end{array}$ & Indictors & . & 交 & 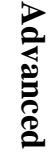 \\
\hline \multirow{9}{*}{$\begin{array}{l}\text { Knowledge } \\
\text { economy }\end{array}$} & Rates of increasing the proportion of trained and developed workers & & & \\
\hline & The rate of developing information and communication technology bases & & & \\
\hline & $\begin{array}{l}\text { The percentage of the IT sector's contribution to developing the local product } \\
\text { structure and increasing the products }\end{array}$ & & & \\
\hline & Increasing the worker's share of the local product & & & \\
\hline & $\begin{array}{l}\text { The percentage of economic institutions (entrepreneurship) that implement } \\
\text { productive innovations and modern production technology }\end{array}$ & & & \\
\hline & $\begin{array}{l}\text { The rates of introducing new technologies into production methods, especially } \\
\text { those that limit waste and reduce resource use. }\end{array}$ & & & \\
\hline & Increased $\%$ of innovative products from the total industrial production. & & & \\
\hline & $\begin{array}{l}\text { Increase } \% \text { of sales of technologically and innovative industrial products out of } \\
\text { total industrial sales }\end{array}$ & & & \\
\hline & Ratio of IT-based products to traditional products & & & \\
\hline \multirow{5}{*}{$\begin{array}{l}\text { Sharing } \\
\text { economy }\end{array}$} & E-commerce volume & & & \\
\hline & Number of households used to shop on line & & & \\
\hline & $\begin{array}{l}\text { The percentage of increasing the financing of technological infrastructure projects } \\
\text { from government funding }\end{array}$ & & & \\
\hline & The number of workers in independent businesses via the internet & & & \\
\hline & The number of users on smartphones & & & \\
\hline
\end{tabular}


International Journal of Engineering Research and Technology. ISSN 0974-3154, Volume 13, Number 11 (2020), pp. 3431 -3443

(C) International Research Publication House. https://dx.doi.org/10.37624/IJERT/13.11.2020.3431-3443

\begin{tabular}{|c|c|c|c|c|}
\hline $\begin{array}{c}\text { Types of } \\
\text { Tec- } \\
\text { economic }\end{array}$ & Indictors & 흄. & 交 & $\begin{array}{l}\sum_{0}^{2} \\
\vdots \\
0 \\
0 \\
0\end{array}$ \\
\hline & Number of companies with a web sit & & & \\
\hline & Number of social media users & & & \\
\hline & Number of companies with special speeds on the Internet & & & \\
\hline & $\begin{array}{l}\text { Percentage of the volume of internal investments resulting from the existence of } \\
\text { an ICT }\end{array}$ & & & \\
\hline \multirow{10}{*}{$\begin{array}{l}\text { Competitive } \\
\text { economy }\end{array}$} & The volume of costs of using local resources & & & \\
\hline & The rationalization of the use of non-renewable energy & & & \\
\hline & $\begin{array}{l}\text { The volume of foreign investment wave } \\
\text { Profit rates }\end{array}$ & & & \\
\hline & The extent of raising the comparative advantage of the smart economy & & & \\
\hline & Increase productivity & & & \\
\hline & Costs of trained labor & & & \\
\hline & The size of growth in exports from small and medium enterprises & & & \\
\hline & $\begin{array}{l}\text { The rates of the contribution of the mutual production in the volume of antibiotics } \\
\text { from the local product }\end{array}$ & & & \\
\hline & Technology Contribution to Trade & & & \\
\hline & Small enterprise growth rates & & & \\
\hline \multirow[t]{4}{*}{$\begin{array}{r}\text { Digital } \\
\text { economy }\end{array}$} & $\begin{array}{l}\text { Number of private companies that rely on information and communications } \\
\text { technology }\end{array}$ & & & \\
\hline & The total volume of services related to electronic platforms & & & \\
\hline & The free availability of digital services to families and industrial establishments & & & \\
\hline & Number of companies using and connected to the internet & & & \\
\hline
\end{tabular}


International Journal of Engineering Research and Technology. ISSN 0974-3154, Volume 13, Number 11 (2020), pp. 3431 -3443

(C) International Research Publication House. https://dx.doi.org/10.37624/IJERT/13.11.2020.3431-3443

\begin{tabular}{|l|l|l|l|}
\hline $\begin{array}{c}\text { Types of } \\
\text { Tec- } \\
\text { economic }\end{array}$ & \multicolumn{1}{|c|}{ Indictors } & & \\
\hline \multirow{2}{*}{} & Number of individuals using digital services & & \\
\cline { 2 - 5 } & The number of companies used for Internet marketing & & \\
\cline { 2 - 5 } & The number of families connected to the Internet & & \\
\cline { 2 - 5 } & Number of commercial sales online & & \\
\end{tabular}

relevant aspect

less relevant aspect

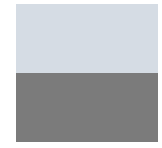

\section{A Design of initial rapid rating system of smart economy}

The proposed rapid rating system for identifying the elements of smart economics in cities consists of a set of indicators that expresses its concept and its use through 4 steps to verify the existence of the needs and constituents of the transition towards it. The first check, knowing the extent of the city's orientation towards smartness. The second check, is a trial of the basics of building a smart economy. The third check is a trial of the extent to the medium stage of building smart economy has been achieved. The fourth check is the extent of progress in building the system and the effects of this system on the current economic.as shown in table 7 and the process of rating system as shown in Figure 5

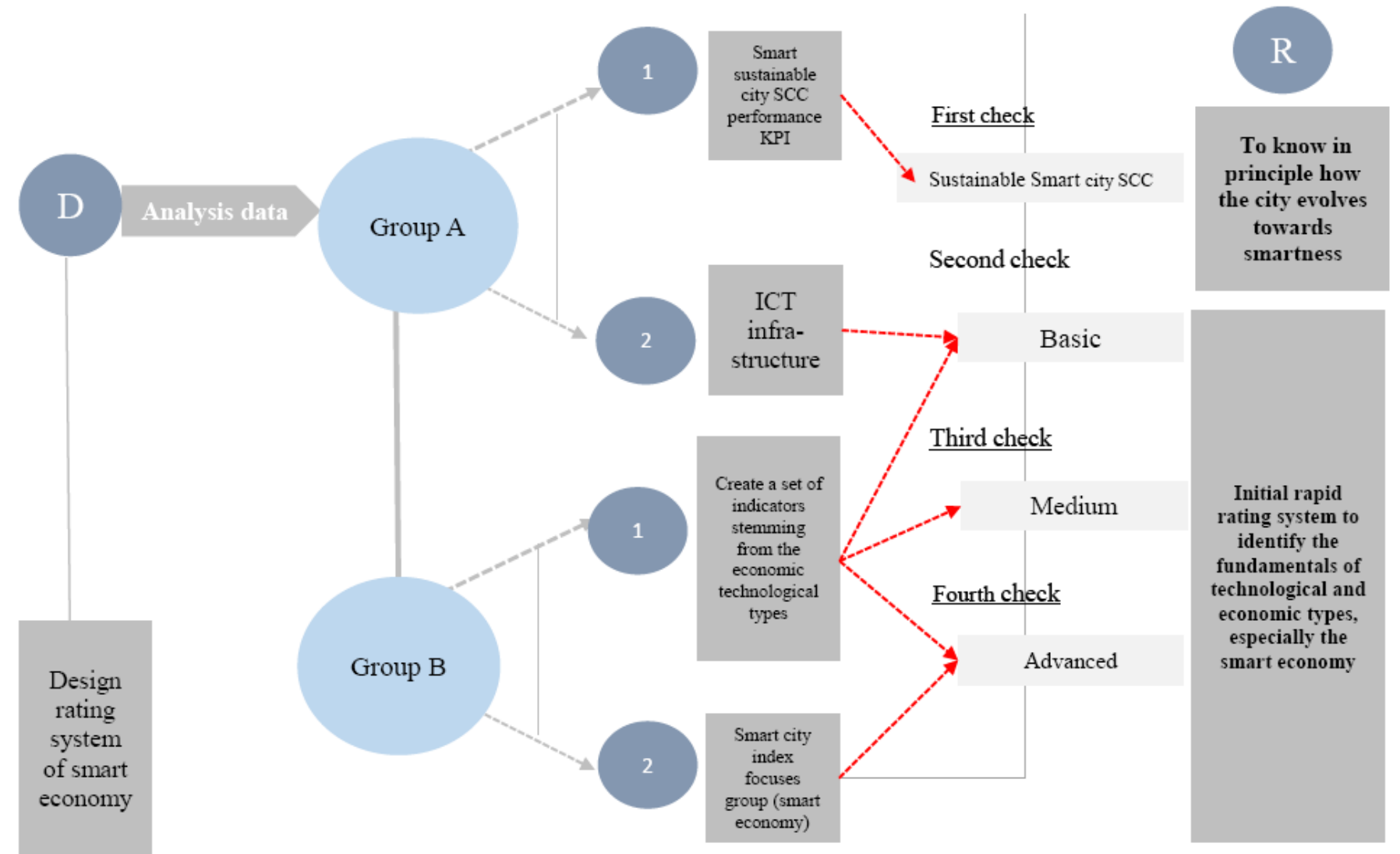

Figure 5: A Design of initial rapid rating system of smart economy 


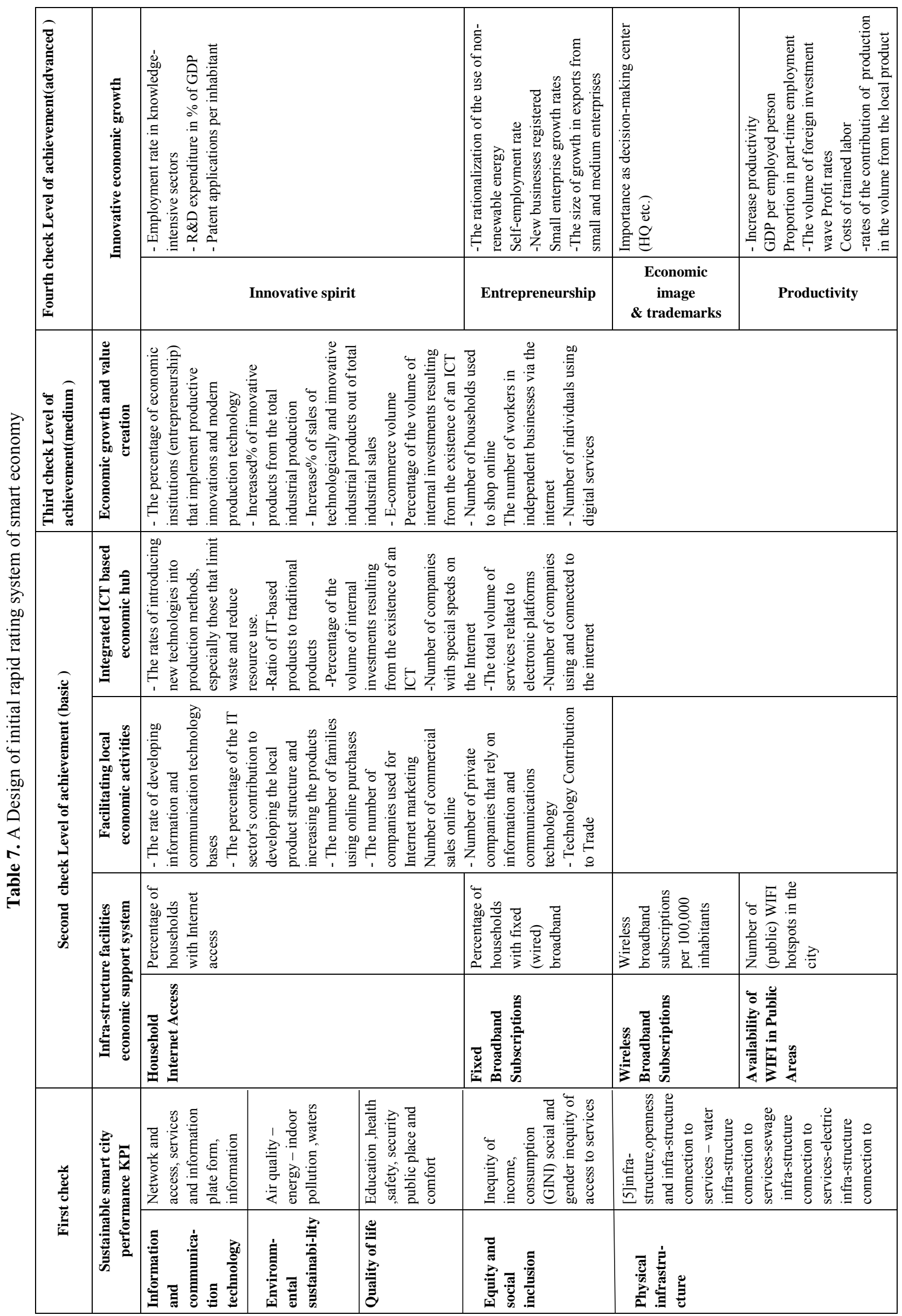


International Journal of Engineering Research and Technology. ISSN 0974-3154, Volume 13, Number 11 (2020), pp. 3431-3443

(C) International Research Publication House. https://dx.doi.org/10.37624/IJERT/13.11.2020.3431-3443

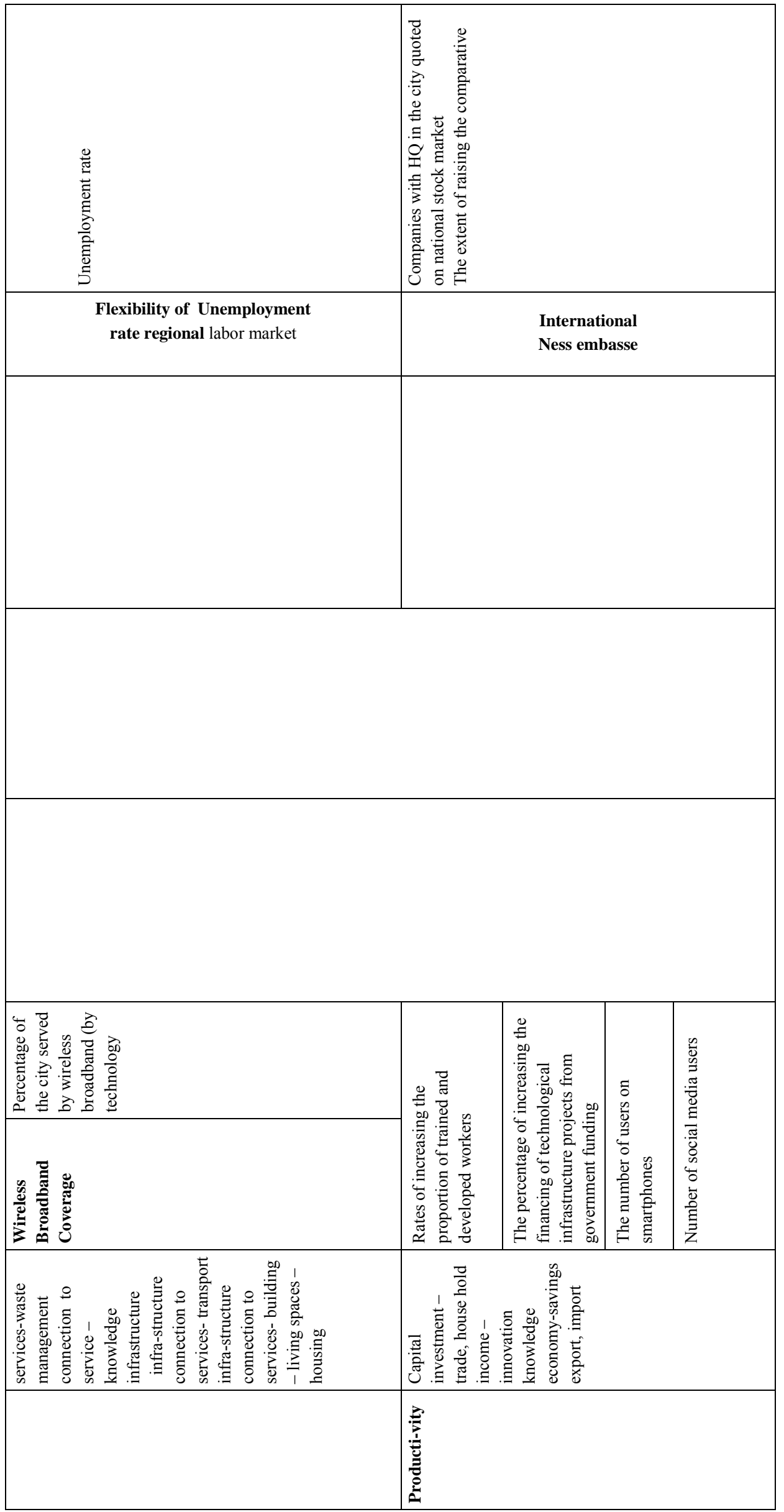


International Journal of Engineering Research and Technology. ISSN 0974-3154, Volume 13, Number 11 (2020), pp. 3431 -3443

(C) International Research Publication House. https://dx.doi.org/10.37624/IJERT/13.11.2020.3431-3443

\section{CONCLUSION}

Referring to the main research objective, the following results were obtained:

- The concept of smart economy can be formulated as the last type of technological economics which helps the cities to change the frame work of current economy. [4] It combines features of technological economics "knowledge economy, Competitive economy, share economy, digital economy" with the current economy to increase productivity and raise environmental efficiency [6], [2]. In order to reach the development decisions for the sustainability and development of cities oriented towards smartness.

- According to this inferred concept of smart economy, the main idea has been reached, which is that the process of building it depends on progressive development of technological economic systems, for example (knowledge, competitive, sharing, and digital economic).

- One of the most important approaches of smart economy that is appropriate for the Egyptian case study is (Level Of Achievement) because there is difficulty in finding databases that monitor the current status of the progressive development to build the smart economy so the basics are searched and then the development in construction Then search for progress in construction, so The basics will be searched, and construction will progress, then the search will be advanced in construction.

- Achieving the goal of research in designing a rapid rating system of smart economy appropriate to the Egyptian case study to reach an initial rapid monitoring of the available capabilities for easily making decision.

\section{REFERENCES}

[1] W. Musa, "The Impact of Smart City Initiatives on Cities'," 2017.

[2] T. W. P. Tyas, "Applying Smart Economy of Smart Cities in Developing World," 2019.

[3] G. M. T. Charlie Karlsson, "ICT Diffusion, Innovation Systems, Globalisation and Regional Economic Dynamics: Theory and Empirical Evidence," esri, 2008.

[4] C. Eboagu, "Evaluation of ICT development and economic growth in AfricaNgozi," 2019.

[5] H. H. M. D. Yasmin Mohd Adnan, "Comparative Overview of Smart Cities Initiatives: Singapore and Seoul," researchgate, 2016.

[6] T. K. T.M.Vinod Kumar, "Smart Economy in Smart Cities," researchgate, 2017.

[7] Gargiulo, "Urban Smartness Vs Urban Competitiveness: A Comparison of Italian Cities Rankings.," 2014.

[8] united nation,"smart city plan," 2018.

[9] T. N. H. Minako Hara, "New Key Performance
Indicators for a Smart," sustainability,MDPI, 2016.

[10] T. Z. Eduardo Moreira Da Costa1, "Smartness that matters: towards a comprehensive and human-centred characterisation of smart cities," 2016.

[11] Schipper, " Characteristics of Smart Sustainable City Development: Implications for Project Management.," 2018.

[12] R. Daugeliene, "Towards knowledge-based economy: modeling knowledge expression assessment.," 2016.

[13] Ö. Karahan, "INPUT - OUTPUT INDICATORS OF KNOWLEDGE-BASED ECONOMY AND TURKEY," 2012.

[14] O. V. Ganna Kharlamova, "The International Competitiveness ofCountries: Economic-Mathematical Approach, Economics," 2013.

[15] A. Z. Tomasz Siudek, "COMPETITIVENESS IN THE ECONOMIC CONCEPTS,," 2014.

[16] G. Gorog, "The Definitions of Sharing Economy:A Systematic LiteratureReview.," 2019.

[17] H. d. Roover, "A framework to analyse a sharing economy," 2017.

[18] Ahmad, "Towards a Framework for Measuring the Digital Economy, (OECD)," 2018.

[19] M. D. Nela Milošević, "Digital economy in Europe: Evaluation of," 2018.

[20] D. J. Manyika, "Digital Economy: Trends, Opportunities and Challenges," 2018.

[21] C. o. R. Science, "Smart cities Ranking of European medium-sized cities," Vienna, 2017.

[22] M. G. Karin Axelsson, "Stakeholders' stake and relation to smartness in smart city development Insights from a Swedish city planning project," 2018.

[23] P. B. M. Aapo Huovilaa, "Comparative analysis of standardized indicators for Smart sustainable cities: What indicators and standards to use and when? Airaksinenc.," 2019.

[24] E. Civilization, "Sustainable Development Strategy (SDS): Egypt Vision 2030",," 2015.

[25] H.-M. N. H. Peter Bosch, "Recommendations for a smart city index," 2016.

[26] Ö. Karahan, "INPUT - OUTPUT INDICATORS OF KNOWLEDGE-BASED ECONOMY AND TURKEY," 2012. 